\title{
Correlation Between the Vitamin D Intake with Clinical Symptoms of Patients Pulmonary Tuberculosis
}

\author{
Netti Suharti ${ }^{1}$, Teda Faadhila ${ }^{2}$, Delmi Sulastri ${ }^{3}$ \\ ${ }^{I}$ Microbiology Department, Andalas University, Indonesia \\ netti_suharti@yahoo.co.id \\ ${ }^{2}$ Medical Faculty, Andalas University, Indonesia \\ tedafaadhila@yahoo.com \\ ${ }^{3}$ Nutrition Department, Andalas University, Indonesia \\ delmisulastri@yahoo.com
}

\begin{abstract}
Vitamin D is known to enhance the immune response to mycobacteria. Approximately one million people worldwide are estimated to have vitamin $D$ deficiency or insufficiency. Clinical symptoms of pulmonary TB patients affected by the immune response to mycobacteria and are not directly influenced by vitamin $D$. The aim of this study was to determine the correlation between vitamin D intake with clinical symptoms of patients with pulmonary tuberculosis. The method of this study was cross sectional study to 52 patients pulmonary tuberculosis. They were interviewed with a questionnaire FFQ. The amount of vitamin $D$ intake was calculated by using the software nutri survey. Clinical symptoms of TB patients measured by using Bandim TBScore. They are divided into three categories: TBScore grade I (mild), TBScore grade II (moderate) and TB Score grade III (severe). Statistical analysis of the two variables were allegedly linked using SPSS software. In this study the average intake of vitamin $D$ respondents is $\mathbf{5 . 8 6} \pm \mathbf{5 . 4 5}$ mcg. This number is very small compared with the minimum level of dietary vitamin recommended for Indonesian per person per day $(15 \mathrm{mcg})$. In this study the respondents who have TBScore grade I was $92.3 \%$, the respondents who have TBScore grade II was $7.69 \%$ and none of the respondents who have TBScore grade III. The avergage of TBScore is $2,04 \pm 1,89$. Based on the statistical analysis, $p$ value is 0,243 ( $p>0.05$ ). Thus, it can be concluded that there was no significant association between the intake of vitamin $D$ with clinical symptoms of pulmonary TB patients in the Padang city.
\end{abstract}

Keywords - Tuberculosis, Vitamin D, Immune system, TBScore, Nutrition

\section{INTRODUCTION}

Tuberculosis (TB) is one of the major public health problems today and included in the global emergency. TB is the leading cause of death due to second infection after HIV in worldwide. By 2013 it is estimated at about 9 million people suffer from TB and 1,5 million people died from TB worldwide, 360.000 of whom are HIV-positive [1].
More than half of TB patients in the world (56\%) are in Southeast Asia and the Western Pacific region. Most cases are in Africa, a quarter of all cases with an incidence of 280 per 100,000 population. The six countries with the highest TB incidence in 2013 were India (2.0 -2.3 million), China (0.9-1.1 million), Nigeria (340.000-880000), Pakistan (370.000-650.000), Indonesia (410.000520.000) and South Africa (410.000-520.000) [1].

The prevalence of TB in Indonesia is $0.4 \%$ with the highest prevalence found in West Java $(0,7 \%)$, Papua $(0,6 \%)$, Jakarta $(0,6 \%)$, Gorontalo $(0,5 \%)$, Banten $(0,4 \%)$ and West Papua $(0,4 \%)$. West Sumatra has a prevalence $0,2 \%$ [2]. Based on the annual report of the Padang City Health Department in 2013, found positive pulmonary tuberculosis patients $925(11,56 \%)$ of 8.005 suspected pulmonary tuberculosis. When compared with the past few years, cases of pulmonary TB continues to rise. In 2012 the number of positive pulmonary tuberculosis patients as many as 603 , as many as 680 cases in 2011, 2010 as many as 853 cases, 2009 were 748 cases and in 2008 as many as 699 cases [3].

The percentage of patients with pulmonary TB, Acid Fast Bacilli (AFB) + who recovered after completion of the treatment period is called the cure rate. The cure rate of West Sumatra in 2004 and 2005 is almost close to the national target of $85 \%$ [4].

There are several factors that influence the success of TB treatment including gender, age, 
diabetes mellitus, HIV, pregnancy, malnutrition, smoking, corticosteroid therapy, genetic factors, terminal kidney disease, social or environmental and compliance [5].

Approximately one million people worldwide are estimated to have vitamin $\mathrm{D}$ deficiency or insufficiency, defined insufficiency was levels of 25 $(\mathrm{OH}) \mathrm{D}=30 \mathrm{ng} / \mathrm{mL}$ [6]. Indonesia is also experiencing the same thing. Research in 48 districts in Indonesia, which includes 300 children aged 2-12 years showed that Indonesian children consume the food source of calcium and vitamin D were lower than the recommended nutrient adequacy [7].

Vitamin D is used in the treatment of TB in the preantibiotik era. Cod liver oil is often used to treat patients with rickets and TB. In the mid 19th century, Williams reported that there is improvement in patients with pulmonary tuberculosis after consuming large amounts of vitamin $\mathrm{D}_{3}$. Then begin vitamin $\mathrm{D}_{3}$ isolated from cod liver oil to treat tuberculosis there in 1930 and is widely used to treat and prevent TB until the discovery of antibiotics in 1950 [8]. Vitamin D may improve the immune response to mycobacteria. Vitamin D deficiency is common in patients with active TB [9].

Clinical symptoms of TB patients is influenced by a host of factors, microbial factors and the interaction with the microbial host. Host of factors including the age, immune status, comorbidities and BCG immunization. Microbial virulence factors, among others, and a predilection for a particular network. As well, the interaction of host and microbes that includes the body part involved and the severity of the disease [10].

Research conducted by Martineau et al in London on 192 healthy adults who had a history of contact with an active TB patients showed an increase in immunity of mycobacterium tuberculosis in the group given $2,5 \mathrm{mg}$ of vitamin $\mathrm{D}$ for 6 weeks. Measurements were made with BCG lux assay method. Showed that the group receiving vitamin $\mathrm{D}$ has a BCG mean 24-hour lux assay luminencence ratio is $20 \%$ lower than the group who received a placebo, in other words, vitamin $\mathrm{D}$ can reduce the viability of the bacteria Mycobacterium Tuberculosis [11].
The aim of this study was to determine the correlation between vitamin D intake with clinical symptoms of patients with pulmonary tuberculosis.

\section{METHODS}

The method of this study was cross sectional study to 52 patients pulmonary tuberculosis. They were interviewed with a questionnaire FFQ. The mean of vitamin D intake was calculated by using the software nutrisurvey. Clinical symptoms of TB patients measured by using Bandim TBScore. They are divided into three categories: TBScore grade I (mild), TBScore grade II (moderate) and TB Score grade III (severe). Statistical analysis of the two variables using T test with SPSS software.

\section{RESULTS}

The results can be known by the presentation of the following.

TABLE I

THE FREQUENCY DISTRIBUTION OF THE LEVEL OF CLINICAL SYMPTOMS

\begin{tabular}{|l|c|c|}
\hline \multicolumn{1}{|c|}{ TB Score } & f & \% \\
\hline Level I & 48 & 92,3 \\
\hline Level II & 4 & 7,69 \\
\hline Total & $\mathbf{5 2}$ & $\mathbf{1 0 0}$ \\
\hline
\end{tabular}

Table 1 known that most respondents have a level I TB Score is 49 people $(92,3 \%)$.

TABLE II

THE AVERAGE OF TB SCORE AND VITAMIN D INTAKE

\begin{tabular}{|l|c|c|}
\hline \multicolumn{1}{|c|}{ Variable } & $\mathbf{X} \pm$ SD & Min-Max \\
\hline TB Score & $2,04 \pm 1,89$ & $0-7$ \\
\hline Vitamin D Intake & $5,86 \pm 5,45$ & $0,1-24,4$ \\
\hline
\end{tabular}

Table 2 that the average TB Score respondent is $2,04 \pm 1,89 \mathrm{mcg}$.

The average vitamin $\mathrm{D}$ intake respondent 5,86 $\pm 5,45 \mathrm{mcg}$. This amount is very low if compared to the minimum level of dietary vitamin recommended for people Indonesia per person per day by the Minister of Health Republic of Indonesia Regulation 2013 is $15 \mathrm{mcg}$.

TABLE III

CORRELATION BETWEEN VITAMIN D INTAKE WITH CLINICAL SYMPTOMS OF PATIENTS PULMONARY TUBERCULOSIS 


\begin{tabular}{|l|c|c|c|}
\hline \multicolumn{1}{|c|}{ Variable } & $\begin{array}{c}\text { Clinical } \\
\text { Sypmtomps }\end{array}$ & $\mathbf{X} \pm$ SD & P value \\
\hline Vitamin D & TB Score I & $6,12 \pm 5,54$ & 0,243 \\
\cline { 2 - 3 } Intake & TB Score II & $2,78 \pm 3,36$ & \\
\hline
\end{tabular}

Table 3 known there is no difference significant between vitamin D intake pulmonary TB patients with clinical symptoms level light with pulmonary TB patients with clinical symptoms of moderate because $\mathrm{p}=0.243(\mathrm{p}$ value $>0,05)$.

\section{IV.DISCUSSION}

Statistical test results in this study was obtained $p$ value $=0.243(p>0.05)$, then those results showed no association between vitamin $\mathrm{D}$ intake with clinical symptoms of pulmonary TB patients because there is no significant difference between the amount of vitamin D intake of pulmonary TB patients clinical symptoms of mild to moderate clinical symptoms. Researchers suspect this is because the ratio of the number of samples in the group of mild clinical symptoms with a group of clinical symptoms were not balanced 48: 4. In addition, both groups had the same average intake of vitamin $\mathrm{D}$ below the recommended so that no visible difference in intake significant. However, if viewed average intake of vitamin $\mathrm{D}$ between the two groups, intake of vitamin D in the group of mild clinical symptoms is higher than the amount of vitamin D in the group of clinical symptoms were.

Based on research conducted Nursyam year 2006, there are no differences in the levels of hemoglobin and BMI were significant between the group receiving Anti TB Drugs (ATB) and Vitamin D and the group receiving ATB and placebo. Hemoglobin and $\mathrm{BMI}$ is a component in determining the level of clinical symptoms of pulmonary $\mathrm{TB}$ patients. However, there are significant differences in terms of the conversion of sputum and radiological picture among the group given vitamin $\mathrm{D}$ with the group given placebo. This proves that vitamin $\mathrm{D}$ does affect the cellular immune system [12].

Desai in 2012 reported that TB patients newly diagnosed with vitamin $\mathrm{D}$ deficiency due to inadequate food intake and lack of patient exposure to sunlight. Vitamin D is a compound that can be synthesized in the skin and it is the main source of vitamin D for many people [13]. Source of food is only necessary if insufficient exposure to the sun [14]. After exposure to UVB rays (UVB: 290-315 nm), UVB photon beam causes photolysis of 7 dehydrocholesterol into pravitamin D3, pravitamin D3 then undergoes thermal isomerization at a temperature of $37^{\circ} \mathrm{C}$ to vitamin D [15].

Determinant of vitamin D status consists of; exposure to UVB radiation, clothing, nutrition, BMI, serum cholesterol, and genetic factors like skin pigmentation and enzymes in the metabolism of vitamin D [16]. Exposure to UV radiation is the most determinant factor [17].

Serum levels of vitamin D increase progressively in line with increased exposure to UV rays. Research conducted by Shalliker in 2013 to 208 healthy people showed that. Questionnaires were administered consisted of demographic characteristics, diet, alcohol, amount of time spent outdoors during 09:00 to 17:00 pm for 16 weeks, use of sunscreen and sensitivity. Week 16 all blood samples were collected and the results are curvilinear relationship between serum levels of vitamin $D$ with exposure to UV rays; serum 25 $(\mathrm{OH}) \mathrm{D}$ increases with increasing exposure to UV rays up to $89 \mathrm{nmol} / \mathrm{L}$ and then decreased at higher exposure [18].

Food intake is usually considered sufficient to represent vitamin D status if exposure to sunlight is ignored [19]. In a study conducted by Lumsden in 2007 shows that there is a weak relationship between dietary intake and serum $25(\mathrm{OH}) \mathrm{D}$ in the TB group. Instead, the assessment of exposure to only UV light is not enough to describe the status of vitamin D [20]. Mc Carty in 2008 tried to calculate the status of vitamin D through sunlight exposure questionnaire. However, the calculation of vitamin D status through questionnaires sunlight exposure is less representative because a low correlation with serum levels of vitamin D [21].

Researchers have yet to find the factors that influence it. Absence of relationship between vitamin $\mathrm{D}$ intake with clinical symptoms of pulmonary TB patients in the Padang City is influenced by several things. These factors associated with the immune system. The immune system is a complex and influenced by many things. In this study, samples of 18-60 years old. At this age the immune system that are in the best 
conditions. In old age, already there is a decrease in the production of $\mathrm{B}$ cells and $\mathrm{T}$ cells in the bone marrow and thymus, and decreased function of mature lymphocytes in secondary lymphoid tissues [22].

In infants and children the immune system is not yet fully developed. Lymphoid organs gradually add mass during maturation and do not reach full weight into adulthood. The average number peyer plate is half the number mature at birth and gradually increased until the average number of adults exceeded the aged teens [23]. Meanwhile, at the young age of the production and function of immune cells are still going well. B cells produce antibodies that attach to cells and helps destroy pathogens. The set $\mathrm{T}$ consists of, helper $\mathrm{T}$ cells and killer T cells. Helper T cells help B cells to produce antibodies and also increases the ability of macrophages to fight pathogens [24].

Another factor is the macronutrient intake. Macronutrient consisting of carbohydrates, fats and proteins. In the immune system, macronutrient most plays is protein. Protein in patients required to establish a cytokine that is used in the body's defense system. The amount of cytokines in the body will affect the patient's immune system. Cytokines are proteins that regulate interactions between cells and play a role in the activation of $T$ cells, B cells, monocytes, macrophages, inflammation and induction of cytotoxicity [25]. In research that has similarities conducted by Sari in 2015 of the same sample obtained an average intake of protein samples according to the recommended amount, that is equal to 78,477 grams / day. If viewed in terms of the protein supply, the sample is expected to have an adequate immune system partly because of this factor.

Body Mass Index is also known to affect the immune system. In this study, $38(73 \%)$ patients had a normal BMI (>18). Research conducted by Ilavska in 2012 indicates that there is a strong relationship between BMI with the human immune system. This is especially more pronounced in women. Parameters that he took as a measure of immune system enhancement, among others, CD3, CD4, CD8, CD16 + 56, CD19, HLADR, CD11b, CD11c, and CD54 [26]. Moreover, undernutrition associated with suppression of antigen-specific arms of the immune system, decreasing the proliferation of $\mathrm{T}$ lymphocytes and lymphoid tissue atrophy. Koethe research in 2011 shows HIV patients with lower BMI and with the increase in BMI of less than $10 \%$ during the follow-up significantly reduces the recovery of CD4+ lymphocytes. In this study, CD4 + lymphocyte recovery seen greater in the group of overweight [27]. Currently known term "obesity paradox" which is estimated obesity associated with improved prognosis in patients with critical illness, but the explanation of this is unclear [28].

\section{CONCLUSSION}

The results of this study can be concluded that there was no significant association between the intake of vitamin $\mathrm{D}$ with clinical symptoms of pulmonary TB patients in the Padang City.

\section{REFERENCES}

[1] WHO. (2014) Global Tuberculossis Report. [Online]. Available: http://apps.who.int/iris/bitstream/10665/137094/1/9789241564809eng. pdf.

[2] Basic Health Research Republic Of Indonesia, Basic Health Research Republic of Indonesia 2013. Jakarta, Ministry of Health Republic of Indonesia, 2013.

[3] Health Departement of Padang City, Padang City Health Profile in 2012. Padang City, Health Departement, 2013.

[4] Price SA, Wilson LM, Patofisiologi: Konsep Klinis Proses-Proses Penyakit, Jakarta, EGC, 2003.

[5] Masriani L, Priyanti ZS, Tjandra YA, "Faktor-faktor yang Mempengaruhi Kesembuhan Penderita TB Paru," J Respir Indo., vol. 7, 2007.

[6] Holick,MF, "Vitamin D Deficiency," N Engl Jmed, vol. 357, pp. 26681,2007

[7] Valentina V, Palupi NS, Andarwulan N, "Asupan Kalsium dan Vitamin D pada Anak Indonesia Usia 2-12 Tahun," J. Teknol. dan Industri pangan, vol. 25, Jan. 2014.

[8] Amin, M, Ilmu Penyakit Paru, Surabaya, Departemen Ilmu Penyakit Paru FK Unair RSUD Dr. Soetomo, 2010

[9] Martineau, AR, "Old Wine In New Bottles: Vitamin D in the Treatment and Prevention of Tuberculosis," in Proc. Nutrition Society, 2012, paper $71: 84-89$.

[10] American Thoracic Society, "Diagnostic Standards and Classification of Tuberculosis in Adults and Children," Am J Respir Crit Care Med., vol. 161 : 1376-1395, 2000.

[11] Martineau AR, Wilkinson RJ, Wilkinson KA, Newton SM, Kampmann B, Hall BM, et al, "A Single Dose of Vitamin D Enhances Immunity to Mycobacteria," Am J Respir Crit Care Med., vol. 176 : 208-1395, 213, 2007

[12] Nursyam, EW, Amin Z, Rumende CM, "The effect of vitamin D as supplementary treatment in patients with moderately advanced pulmonary tuberculous lesion," Acta Med Indones-Indones J Intern Med., vol. 38, Jan, 2006

[13] Desai NS, Tukvadze N, Frediani JK, Kipiani M, Sanikidze E, Nichols MM., et al, "Effects of sunlight and diet on vitamin D status of pulmonary tuberculosis patients in Tbilisi, Georgia," Nutrition., vol. $28: 362-366,2012$.

[14] Bender DA, Mayes PA, Mikronutrien : Vitamin \& Mineral Dalam Biokimia Harper. Jakarta, Penerbit Buku Kedokteran EGC, 2006.

[15] NimitphongH, Holick MF "Vitamin D status and sun exposure in southeast asia," Landes Bioscience, vol. 5 : 34-37, 2013. 
[16] Ralph A P, Waramori G, Pontororing G J, et al, "Arginine and vitamin $\mathrm{D}$ adjunctive therapies in pulmonary tuberculosis: a randomised, double blind, placebo-controlled trial," PLOS ONE, vol. 28, 2013.

[17] Morris, HA, "Vitamin D: A hormone for all seasons - how muc enough? understanding the new pressures," Clin Biochem Rev, vol. 25 2004

[18] Shalliker VN, Clements M, Fenech M, Armstrong BK "Personal sun exposure and serum 25-hydroxy vitamin d concentrations," Photochemistry and Photobiology, vol. 89 : 208-214, 2013.

[19] Wejse C, Olesen R, Rabna P, Kaestel P, Gustafson P, Aaby P, et al "Serum 25-hydroxyvitamin D in a west african population of tuberculosis patients and unmatched healthy controls," Am J Clin Nutr, vol. $86: 1376-83,2007$.

[20] Lumsden AS, Lapthorn G, Swaminathan R, Milburn H J "Reactivation of tuberculosis and vitamin D deficiency: The contribution of diet and exposure to sunlight," Thorax, vol. 62: 1003-1007, 2007.

[21] McCarty CA "Sunlight exposure assessment: can we accurately assess vitamin D exposure from sunlight questionnaires?," Am J Clin Nutr, vol. 87: 1097S-101S, 2008.

[22] Rodriguez EM, Maoz BB, Dorshkind K, "Causes, consequences, and reversal of immune system aging," J Clin Invest, vol. 123: 958-965, 2013.

[23] Buckley, RH, "Primary immunodeficiency disease due to defects in lymphocytes," N Engl J med, vol. 343: 1312-1324, 2000

[24] Japanese Society for Immunology, Your amazing immune system European Federation of Immunological Societies (EFIS). Japan, Japanese Society for Immunology, 2009.

[25] Bratawidjaja KG, Rengganis I, Imunologi dasar edisi ke-10. Jakarta, , Badan Penerbit Fakultas Kedokteran Universitas Indonesia, 2012.

[26] Ilavská S, Horváthová M, Szabová M, Nemessányi T, Jahnová E, Tulinská $\mathrm{J}$, et al, "Association between the human immune response and body mass index," Hum Immunol vol. 73: 480-485, 2012

[27] Koethe JR, Jenkins CA, Shepherd BE, Stinnette SE, Sterling TR, "An optimal body mass index range associated with improved immune reconstitution among hiv-infected adults initiating antiretroviral therapy," Clinical Infectious Diseases, vol. 53: 952-960, 2011

[28] Zampieri FG, Jacob V, Barbeiro HV, Silva FP, Souza HP, "Influence of body mass index on inflammatory profile at admission in critically ill septic patients," International Journal of Inflammation, 2015. 